\title{
Efektivitas Pemberian Reward dalam Pembelajaran IPS untuk Meningkatkan Motivasi Belajar Kelas VII Mts. Negeri Margadana Kota Tegal
}

\section{Adefyanti Dwi Indah Fatonah, Arif Purnomo, Rudi Salam $\bowtie$}

Social Science Education Department, Faculty of Social Science, Universitas Negeri Semarang, Indonesia

\begin{tabular}{l}
\hline Info Artikel \\
\hline Sejarah Artikel: \\
Disubmit: \\
Direvisi : \\
Diterima: \\
\hline Keywords: \\
reward; learning motivation. \\
\hline
\end{tabular}

\begin{abstract}
Abstrak
Penelitian ini bertujuan untuk mengetahui efektivitas pemberian reward dalam pembelajaran IPS untuk meningkatkan motivasi belajar kelas VII di MTs Negeri Margadana Kota tegal. Alasan mengambil penelitian ini karena kesadaran guru di sana untuk memberikan motivasi kepada siswanya masih minim dan juga rendahnya aktivitas siswa dalam mengikuti pembelajaran. Desain dari penelitian ini adalah Eksperimen Quasi Nonequivalent Control Group Design. Populasi dari penelitian ini adalah siswa kelas VII MTs Negeri Margadana Kota Tegal. Sampel dari penelitian adalah siswa kelas VII G dan Kelas VII H dengan teknik sampling purpusive sampling. Alat dan teknik pengumpulan data yang digunakan pada penelitian ini adalah observasi, angket, tes, dan dokumentasi. . Teknis analisis data yang digunakan dalam penelitian ini adalah uji normalitas, uji homogenias, uji t. Dalam penelitian ini, diperoleh t hitung bernilai 2,230 dan $t$ tabel pada taraf signifikansi $5 \%$ dengan $t$ tabel 66 adalah 1,66, sehingga $t$ hitung $=2,230>\mathrm{t}$ tabel $=1,66$.
\end{abstract}

\section{Abstract}

This study aims to determine the effectiveness of reward in teaching social studies to enhance learning motivation in class VII MTS Negeri Margadana Tegal. The reason for taking this researchawareness of teachers there to provide motivation for students is still minimal and low activity of students in participating in learning, The design of this study is a Quasi Experiment Nonequivalent Control Group Design. The population of this research is the students of class VII MTs Negeri Margadana Tegal. Samples of the study were students of class VII $G$ and Class $H$ with purpusive sampling technique sampling. Tools and data collection techniques used in this study is the observation, questionnaires, tests, and documentation. The technique of analyzing data used in this study is the normality test, homogenitas test, t-test. In this research, obtained $t$ count value 2,230 and t table at $5 \%$ significance level with t table 66 is 1.66 , so t count $=2,230>t$ table $=1.66$.

(C) 2019 Universitas Negeri Semarang

\footnotetext{
Alamat korespondensi:

Gedung C1 Lantai 1 FIS Unnes

Kampus Sekaran, Gunungpati, Semarang, 50229

E-mail: jurnalsosioliumpips@mail.unnes.ac.id
}

E-ISSN 2685-4929 


\section{PENDAHULUAN}

Pendidikan adalah usaha manusia dalam membina kepribadiannya sesuai dengan nilainilai di dalam masyarakat serta kebudayaannya. Langeveld menyatakan bahwa, pendidikan adalah setiap usaha, pengaruh, perlindungan dan bantuan yang diberikan kepada anak tertuju kepada kedewasaan anak itu, atau lebih tepat membantu anak agar cukup cakap dalam melaksanakan tugas hidupnya sendiri. pengaruh ini datangnya dari orang dewasa (atau yang diciptakan oleh orang dewasa seperti sekolah, buku, putaran hidup sehari-hari, dan sebagainya) dan ditunjukkan kepada orang yang belum dewasa( Hasbullah, 2001:2).

Pendidikan secara umum sangat diperlukan sebagai upaya untuk meningkatkan kualitas hidup manusia. Begitu juga fungsi dan tujuan pendidikan di Indonesia. Seperti yang tertuang dalam UU No. 20 Tahun 2003 tentang Sistem Pendidikan Nasional pasal 3 tentang fungsi dan tujuan, tertulis bahwa pendidikan nasional berfungsi mengembangkan kemampuan dan membentuk watak serta peradaban bangsa yang bermatabat dalam rangka mencerdaskan kehidupan bangsa, bertujuan untuk perkembangannya potensi peserta didik agar menjadi manusia yang beriman dan bertaqwa kepada Tuhan Yang Maha Esa, berakhlak mulia, sehat, berilmu, cakap, kreatif, mandiri, dan menjadi warga yang demokratis serta bertanggung jawab.

Berdasarkan pada tujuan pendidikan nasional tersebut, pada dasarnya masing-masing sekolah mempunyai tujuan yang sama, yaitu untuk mencapai siswa berkualitas. Untuk mencapai tujuan tersebut maka sangat diperlukan peran guru dan orang tua dalam pembelajaran siswa, karena belajar adalah proses dari perkembangan hidup manusia.

Seperti yang terjadi di MTs Negeri Margadana Kota Tegal, dalam pembelajaran disini ada beberapa guru yang masih menggunakan metode yang monoton, dan itu akan sangat membosankan untuk siswanya sendiri. Kurangnya sumber belajar inilah yang menyebabkan guru-guru di MTs Negeri
Margadana Kota Tegal ini selalu menggunakan metode yang monoton. Sarana dan prasarana disana dirasa kurang mendukung bagi guru dalam proses pembelajaran. Permasalahan yang terjadi tidak hanya pada guru saja, tetapi permasalahan juga dihadapi oleh para siswa disana. Mayoritas siswa disana adalah seorang anak dari pedagang Warteg (Warung Tegal) di Jakarta, yang mana mereka di tinggal oleh kedua orang tuanya bekerja di Jakarta, dan mereka biasanya hanya di temani oleh kakek dan neneknya saja. Hal inilah yang menyebabkan seorang anak tidak mendapatkan perhatian yang lebih dari orangtuanya sendiri. Hal itulah yang membuat anak mencari perhatian di luar rumah, baik di lingkungan bermain maupun di sekolah. Anak-anak seringkali membuat ulah dengan berbagai cara, ada yang selalu berangkat sekolah terlambat, tidak memperhatikan guru saat mengajar di kelas, tidak membuat pekerjaan rumah yang telah diberikan guru, dan sebagainya. Kurangnya perhatian dan motivasi dari dalam diri siswa sendiri inilah yang membuat hasil belajar siswa rendah.

Seorang pendidik (guru) harus mampu mencuri perhatian dari siswanya pada saat pembelajaran. Penggunakan metode belajar yang berbeda dan dibuat semenarik mungkin agar siswanya memperhatikan apa yang sedang di jelaskan oleh guru. Serta penggunakan pembelajaran yang berbeda-beda akan membuat siswa merasa tidak bosan saat berada di dalam kelas. Dengan demikian maka siswa akan merasa tidak bosan dan memperhatikan apa yang sedang di jelaskan oleh guru di dalam kelas. Tidak hanya itu saja, seorang guru juga harus mampu membuat siswanya termotivasi dalam belajar. Salah satu caranya yaitu dengan cara memberikan reward (penghargaan), reward disini berupa nilai tambah bagi siswa yang mampu menguasai materi ataupun aktif bertanya dan memberi tanggapan pada saat pembelajaran, sehingga para siswa mempunyai motivasi belajar yang tinggi agar mendapatkan nilai tambah.

Motivasi belajar mempuyai peranan yang sangat penting dalam hal penumbuhan gairah, 
merasa senang dan semangat untuk belajar. Motivasi belajar dapat berasal dari dalam maupun luar diri siswa. Motivasi belajar yang berasal dari dalam diri siswa tumbuh karena adanya semangat untuk meraih prestasi tertinggi, yang didasari oleh kesadaran yang tumbuh dari dalam diri siswa. Sedangkan motivasi belajar siswa yang berasal dari luar diri siswa biasanya muncul akibat terdapat rangsangan-rangsangan belajar yang berasal dari luar, sehingga siswa terpacu untuk menanggapi rangsangan-rangsangan tersebut dengan cara menjadi lebih rajin dalam belajar. Hasil dari rajin belajar ini akan membuat tercapainya prestasi belajar yang lebih tinggi.

Kenyataannya siswa yang mampu membangkitkan motivasi belajar yang berasal dari dalam dirinya sendiri masih tergolong jarang. Hal ini karena kesadaran dari siswanya sendiri untuk berprestasi lebih tinggi masih tergolong terbatas. Maka dari itu, motivasi yang berasal dari luar akan sangat diperlukan untuk mendapatkan perhatian dan tindakan. Pihak yang wajib memperhatikan dan menindaklanjuti hal ini adalah seorang guru. Sebagai seorang motivator, tugas guru adalah mengupayakan motivasi belajar siswa dari luar sehingga nantinya siswa mampu menumbuhkan motivasi belajar mereka dari dalam.

Sebuah proses pembelajaran pasti ada kegagalan dan keberhasilannya. Kegagalan belajar siswa tidak sepenuhnya berasal dari diri siswa tersebut, tetapi juga dapat berasal dari guru yang tidak berhasil dalam memberikan motivasi yang mampu membangkitkan semangat siswa untuk belajar. Keberhasilan belajar siswa tidak lepas dari motivasi siswa yang bersangkutan, oleh karena itu pada dasarnya motivasi berprestasi merupakan faktor yang sangat menentukan keberhasilan siswa. Siswa juga akan lebih termotivasi jika dari hasil belajarnya tersebut mendapatkan penghargaan (reward) yang memuaskan dari guru atau pihak pengajar sebagai tanda penghargaan atas hasil belajarnya tersebut.

MTs Negeri Margadana merupakan salah satu Sekolah Menengah Pertama (SMP) di kecamatan Margadana, yang terletak di jalan pendidikan. Sekolah ini merupakan satu-satunya Sekolah Menengah Pertama (SMP) Negeri yang berbasis agama Islam. Salah satu visi misi sekolah ini adalah menjadi sekolah Islam unggulan dan terpercaya. Peneliti telah melakukan observasi dan wawancara dengan guru di MTs Negeri Margadana Kota Tegal. Alasan peneliti memilih sekolah ini karena MTs Negeri Margadana ini karena masih minimnya kesadaran guru disana untuk memberikan motivasi kepada siswanya, dan juga rendahnya aktivitas siswa dalam mengikuti pembelajaran yang ditunjukan dengan aktivitas mengemukakan ide/gagasan, serta guru tidak memberikan reward kepada siswa sebagai pendorong agar siswa termotivasi dalam belajar.

Berdasarkan pemaparan latar belakang yang telah dijelaskan oleh peneliti maka peneliti mengambil judul "Efektivitas Pemberian Reward dalam Pembelajaran IPS untuk Meningkatkan Motivasi Belajar IPS Siswa Kelas VII di MTs Negeri Margadana Kota Tegal".

\section{METODE}

Metode yang digunalan dalam penelitian ini adalah kuantitatif. Desain dari penelitian ini adalah Eksperimen Quasi Nonequivalent Control Group Design. Populasi dari penelitian ini adalah siswa kelas VII MTs Negeri Margadana Kota Tegal. Sampel dari penelitian adalah siswa kelas VII G dan Kelas VII H dengan teknik sampling purpusive sampling. Alat dan teknik pengumpulan data yang digunakan pada penelitian ini adalah observasi, angket, tes, dan dokumentasi. Teknis analisis data yang digunakan dalam penelitian ini adalah uji normalitas, uji homogenitas dan uji t.

\section{HASIL DAN PEMBAHASAN}

Dalam penelitian ini, untuk mengetahui motivasi peserta didik yang menggunakan pembelajaran menggunakan reward dan pembelajaran tidak menggunakan reward, peserta didik melakukan uji awal dan uji akhir terlebih dahulu, yang hasilnya akan dibandingkan dengan motivasi belajar untuk 
mengetahui seberapa persen peningkatan motivasi belajar siswa sebelum dan sesudah perlakuan dengan pemberian reward. Perbandingan nilai tersebut dapat dihitung dengan menggunakan uji $t$ dengan bantuan SPSS 16.

Diketahui rata-rata kelas eksperimen awal 51,82 skor tertinggi pada kelas eksperimen sebesar 70 dan skor terendah 41, sedangkan ratarata kelas 55,168 skor tertinggi kelas 76 dan skor terendah 45 .

Diketahui rata-rata kelas kontrol awal 61,24 skor tertinggi pada kelas eksperimen sebesar 76 dan skor terendah 48, sedangkan ratarata kelas 62,71 skor tertinggi kelas 76 dan skor terendah 45.

Berdasarkan hasil penelitian, jumlah sampel kelas kontrol berjumlah 34 siswa, sedangkan kelas eksperimen berjumlah 34 siswa. Jika responden $\leq 50$ maka membacanya menggunakan Shapiro-Wilk, dengan hasil uji normalitas dikarena subjek penelitian kurang dari 50, dengan hasil yang diperoleh adalah nilai sig pada uji awal kelas kontrol yaitu 0,584 dan nilai sig pada kelas eksperimen 0,130. Karena 0,584 lebih dari 0,05 dan 0,130 lebih dari 0,05 maka dinyatakan sampel pada kelas kontrol dan eksperimen berdistribusi normal. Hal ini digunakan untuk pertimbangan dalam melakukan analisis selanjutnya.

Uji homogenitas dilakukan untuk mengetahui varians dari berbagai populasi sama atau tidak. Penelitian ini mempunyai nilai signifikan 0,103. Dimana 0,103 lebih besar dari 0,05, karena 0,103 lebih besar dari 0,05 maka dinyatakan sampel pada kelas kontrol dan kelas eksperimen mempunyai varians yang dengan kata lain data homogen.

frekuensi kecenderungan motivasi belajar kelas eksperimen yang berada pada rentang skor lebih dari atau sama dengan 71 masuk pada kategori sangat tinggi sebanyak 12 siswa atau $32,294 \%$, rentang skor lebih dari 55 sampai dengan kurang dari 71 masuk dalam kategori sedang sebanyak 19 siswa atau 55,882\% dan rentang skor kurang dari 55 masuk kategori sangat rendah sebanyak 3 siswa atau $8,823 \%$. frekuensi kecenderungan motivasi belajar kelas kontrol yang berada pada rentang skor lebih dari atau sama dengan 71 masuk pada kategori sangat tinggi sebanyak 3 siswa atau $8,823 \%$, rentang skor lebih dari 55 sampai dengan kurang dari 71 masuk dalam kategori sedang sebanyak 24 siswa atau 70,588\% dan rentang skor kurang dari 55 masuk kategori sangat rendah sebanyak 7 siswa atau 20,588\%.

Uji $t$ test digunakan untuk melihat perbedaan antara kelas sebelum diberikan perlakuan. Berdasarkan uji statistik hasil uji $\mathrm{t}$ menggunakan tabel independent samples test di dapat nilai $t_{\text {hitung }}$ sebesar 2,230 sedangfkan $t$ tabel pada taraf signifikansi $5 \%$ dengan $t_{\text {tabel }}$ $(34+34=68-2=66) 66$ adalah 1,66.

Berdasarkan hasil perhitungan uji $\mathrm{t}$ di peroleh thitung 2,897 sedangkan ttabel 1,66. Karena nilai t hitung $>$ t tabel maka $\mathrm{Ha}$ diterima. Jadi, kesimpulan dari perhitungan uji t adalah terdapat perbedaan motivasi belajar yang signifikan antara kelas yang diberikan reward dibandingkan dengan kelas yang tidak diberikan reward.

\section{SIMPULAN}

Berdasarkan hasil penelitian dan pembahasan dapat disimpulkan: Setelah diterapkan pembelajaran dengan menggunakan pemberian reward diketahui ada perbedaan terhadap motivasi belajar siswa kelas VIIH MTs Margadana Kota Tegal yang menggunakan pemberian reward dibandingkan dengan kelas VIIG MTs Margadana Kota Tegal yang tidak menggunakan pemberian reward. Metode pembelajaran menggunakan pemberian reward lebih efektif dalam meningkatkan motivasi belajar siswa.

Berdasarkan hasil penelitian Efektivitas Pemberian Reward dalam Pembelajaran IPS untuk Meningkatkan Motivasi Belajar IPS Siswa Kelas VII di MTs Negeri Margadana Kota Tegal, peneliti menyarankan agar penerapan reward hendaknya bisa diterapkan oleh guru dalam pembelajaran yang disesuaikan dengan keadaan siswa. Hendaknya guru dalam melaksanakan pembelajaran dapat 
meningkatkan motivasi belajar siswa dengan pemberian reward selama pembelajaran. Serta pada saat guru menerapkan pemberian reward, guru harus mampu memberi pengarahan kepada siswa terlebih dahulu agar para siswa belajar tidak hanya untuk mendapatkan reward.

\section{DAFTAR PUSTAKA}

Hasbullah. 2001. Dasar-Dasar Ilmu Pendidikan. Jakarta: PT Raja Grafindo Persada.

Nasrudin, Feri. 2015. "Pengaruh Pemberian Reward dan Punishment Terhadap Motivasi Belajar Siswa Kelas VI SD Negeri di Sekolah Binaan 2
Kecamatan Bumiayu Kabupaten Brebes". FIP. UNNES. Semarang.

Pusdyastowo, Dwi Atmojo. 2006. "Pengaruh Pemberian Reward dan Reinforcement Negatif Terhadap Motivasi Belajar Siswa Kelas V SD Negeri Kecamatan Kalasan Kabupaten Sleman Tahun Ajaran 2015/2016". FIP. UNY. Yogyakarta.

Slameto. 2003. Metode Penelitian Pendidikan Pendekatan Kuantitatif, Kualitatif dan $R \& D$. Bandung: Alfabeta.

Sukmawati, Hana Gilang. 2017. "Efektivitas Metode Reward untuk Meningkatkan Motivasi Belajar Peserta Didik di SMK Negeri 3 Yogyakarta". Skripsi. Yogyakarta: Jurusan Bimbingan dan Konseling. FIP. UNY. 